論文

\title{
Study on Reaction and Heat Transfer of Reactive Polyurethane System for Reaction Injection Molding
}

\author{
Akihiko KoIwaI, Takaaki Matsuoka, Hideroh Takahashi ${ }^{* 1}$, \\ Yorihide KubOTA, and Hagemu $\mathrm{KaTOH}^{* 2}$ \\ ${ }^{* 1}$ Toyota Central Research and Development Laboratories, INC. \\ Nagakute-cho, Aichi-gun, Aichi-ken, 480-11, Japan \\ *2 Toyota Motor Corporation, Toyota-shi, Aichi-ken, 471, Japan
}

A rheometer with a wide-gap Couette geometry was developed to study reactive kinetics and rheological properties of the reactive polyurethane systems for a reaction injection molding (RIM). Viscosity and temperature changes during the adiabatic reactions were measured for three different polyurethane systems which had gelation times of a few seconds. The viscosity and temperature changes during the RIM process were predicted by a simple rheo-kinetic theory using the material parameters determined from the adiabatic measurements.

A one-dimensional heat transfer analysis program of the RIM system was developed and the temperature profile in the urethan plate was calculated by the pre-determined material parameters. A good agreement was obtained between the measured temperature and the calculated one.

Key words: Reaction Injection Molding / Polyurethan/Reactive Kinetics / Heat Transfer Analysis

\author{
ポリウレタン反応射出成形における反応・熱解析

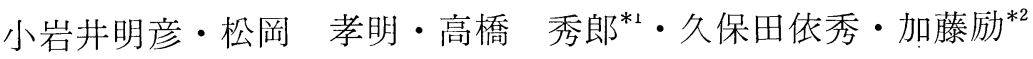 \\ （原稿受理：1989年11月16日）
}

\begin{abstract}
1. 緒言
ポリウレタンの反応射出成形 (以後, RIM と称する) ${ }^{1)}$ は, ポ リオールを主剤とする A 液（粘度約 $1 \mathrm{~Pa} \cdot \mathrm{s}$ ) と, イソシアネー トを主剤とする $\mathrm{B}$ 液（粘度 $1 \mathrm{~Pa} \cdot \mathrm{s}$ 以下）の 2 液を高圧で衝突混 合後金型へ射出し, 金型内で反応・固化させる成形プロセスであ る (Fig. 1). 硬質ウレタン材料は, 工業的には自動車の外装部品 等に使用されている。 RIM では，ボイド（エア溜り），ピンホー ル, 流れ模様, ショートショット等の成形不良があり, 試行錯誤 によりこれらの成形不良に対処する場合が多い。

近年，計算機の進歩によりプラスチックスの成形過程に拈ける

*1 (株)豊田中央研究所 T480-11 愛知県愛知郡長久手町大字長湫字 横道 $41-1$

*2 トヨタ自動車(株) 厂471 愛知県豊田市元町 1
\end{abstract}

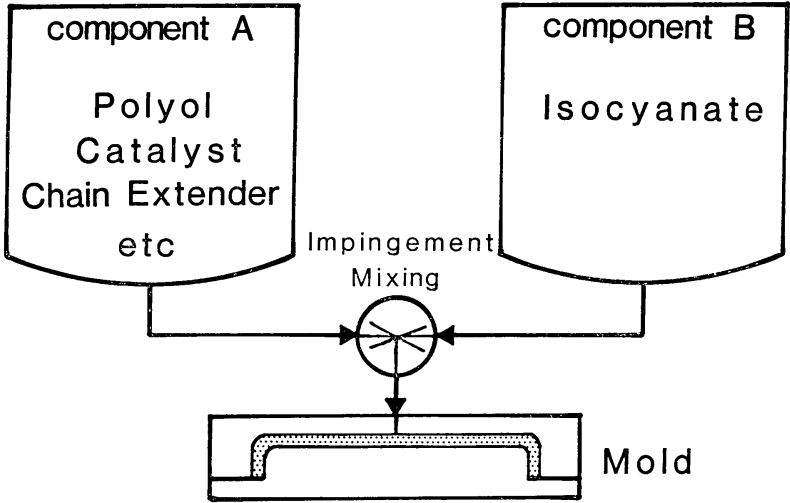

Fig. 1 Schematic diagram of the reaction injection molding. 
樹脂流動等のシミュレーションに関する研究が盛んになりつつあ る. 中でも, 熱可塑性樹脂の射出成形に関しては, 流動・冷却・ 反り等を総合的に解析し，金型招よび成形品の設計・製作，成形 条件の選定等を支援する CAE (Computer Aided Engineering) システムが実用に供されている。

RIM に関しても，成形不良を金型・成形品の設計段階で予測 するために，材料の化学反応，型内流動等を総合的に解析し，金 型・成形品の設計を支援し成形条件の最適化を行う CAE システ ムの開発が望まれる。 RIMは, 射出液が低粘度であり，また，金 型内流動中に化学反応による材料の温度・粘度変化を伴う点で熱 可塑性樹脂の射出成形々相違し, 熱可塑性樹脂の射出成形 $\mathrm{CAE}$ システムをとのまま RIM に利用寸ることはできない，従って， RIM 独自の CAE システムを開発する必要がある.

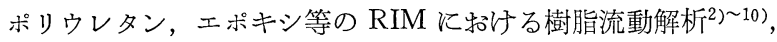

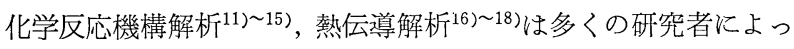
て報告されている。乙かし，これらは熱可塑性樹脂の射出成形 CAE システムと比較して研究段階にとどまっており, 工業的に 利用できるシステムは未だ発表されていない。また，活性が高く ゲル化時間が短い材料系についての研究例は少ない。

樹脂成形 CAE システムでは, 計算手法の確立と同時に, 樹脂 の粘度等の材料特性值の測定が必要不可欠である. RIM では, 成形過程で重合反応による平均分子量 (反応率) の増加に伴い粘 度が増加し，また，反応に伴う発熱に上り材料の温度が上年する. このため, RIM 成形過程のシミュレーションのためには, 反応 機構の解明之粘度の温度 . 反応率依存性の測定が必要である. RIM 材料の反応機構は, 断熱条件下での重合反応（断熱反応） に伴う材料の温度変化の測定により研究されている ${ }^{11) ~ 15) . ~ ま た, ~}$ RIM 材料の重合反応飞伴弓粘度変化は, 等温条件下 ${ }^{19) ~ 22 .) ~}$ と断 熱条件下 ${ }^{23)}$ での研究が報告されている.

断熱条件下では，材料の粘度変化と同時に温度変化を測定する ことにより反応機構の解析ができる，さらに，現実の自動車外装 部品に用いられているウレタン材料は活性が高く短いダル化時間 を持つので，断熱条件に近い状沉で成形が行われていると考える ことができる，従って，自動車の外装部品用のウレタン材料に対 しては，断熱条件下での測定が望ましい。

本研究では，解析に必要な RIM 材料の特性值を測定すること を目的として，RIM 成形機に接続可能で，断熱条件下で測定を 行5回転二重円筒型の RIM 用レオメータを開発した。 また, Macosko ら ${ }^{24)}$ により半経験的に導出された粘度式と $n$ 次の反応

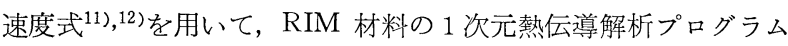
を開発した。

このレオメータを用いて, 数秒のゲル化時間を持つウレタン材 料の断熱反応に伴う粘度・温度变化を測定し, 粘度式および反応 速度式に含まれる材料パラメータを決定した。 また, 決定したパ ラメータを用いて RIM 材料の 1 次元熱伝導計算を行った。

\section{2. 実験}

\section{$2 \cdot 1$ 試料}

自動車の外装部品用である 3 種類の非発泡系ウレタン材料 $\left(S_{1}\right.$, $\left.S_{2}, S_{3}\right)$ について，レオメータを用いて断熱反応に伴万粘度 · 温 度变化を測定した。 これらの材料は架橋剤が異なり, 材料 $S_{1}$ は エチレングリコールとアミンを， $S_{2}$ はエチレングリコールを， $S_{3}$
はアミンを架橋剤として用いた。

\section{$2 \cdot 2$ RIM 用レオメータの構成}

開発した RIM 用レオメータは, 内筒回転式の二重円筒型粘度 計である，このレオメータは，内筒回転数を一定に保持し一定の 剪断速度下で粘度測定を行う。

内筒が受けるトルクを一定に保持して測定を行う粘度計年)では, 内筒のトルク変化を回転制御部へフィードバックし内筒の回転数 を制御する必要があるのに対して，一定の剪断速度下で測定を行 ら粘度計では, トルク変化とは独立に内筒の回転数を制御するこ とができるため，内筒のトルク測定部と回転制御部とを分離する ことができ, システムの構築が容易である。

システムは回転制御部（DC サーボモータ，速度制御器），測 定部（トルク・回転数検出器, 熱電対) およびデータ処理部（マ イクロコンピュータ) より構成され, 内筒回転数を一定に保持し て, トルク検出器でトルク $M$, 回転数検出器で回転数 $\Omega$, 熱電対 で材料の温度 $T$ を測定し， $\mathrm{A} / \mathrm{D}$ ユンバータで信号変換した後マ イクロコンピュータでデータ処理を行う (Fig. 2). また，このレ オメータは RIM 成形機（新潟鉄工所製）と接続される。レオメ 一タの仕様を Table I に示す。

レオメータの回転二重円筒部を Fig. 3 に示す．断熱条件下で 測定するために，外筒（直径 $\phi=85 \mathrm{~mm}$ ）にポリプロピレン製ビ 一カを, 内筒 $(\phi=40 \mathrm{~mm})$ 飞薄肉の SUS 製円柱またはガラス瓶 を用いる．内筒の浸液長 $L$ を一定に保持するために，外筒の上部 は開口とし, 過剩の射出液はビーカ上部より外部へ流出させる。 また，材料内の温度分布を測定し，材料の温度測定と同時に反応 の不均一性を評価することを目的として，熱電対（直径 $0.5 \mathrm{~mm}$ ， シース型アルメルークロメル製）をビーカ下部に 3 本設置する.

ニュートン流体であると仮定すると，材料の粘度クはトルクM

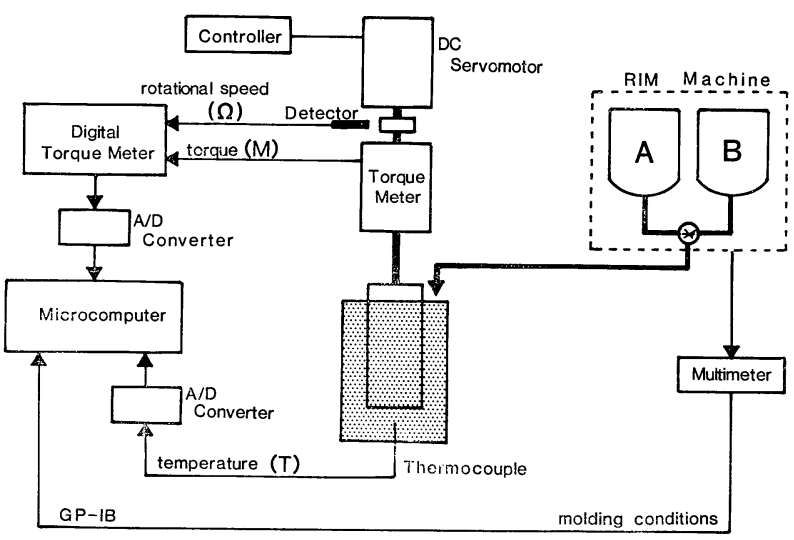

Fig. 2 Outline of the apparatus for measuring temperature and viscosity during adiabatic reaction in RIM system.

Table I. Specific description of the measuring condition of the rheometer for polyurethane RIM systems.

$\begin{array}{llr}\text { Rotational speed } & (\mathrm{rpm}) & 0 \sim 10^{3} \\ \text { Torque } & (\mathrm{kg} \cdot \mathrm{m}) & 0 \sim 0.2 \\ \text { Viscosity } & (\mathrm{Pa} \cdot \mathrm{s}) & 0 \sim 10^{2} \\ \text { Temperature } & \left({ }^{\circ} \mathrm{C}\right) & \text { R.T. } \sim 160\end{array}$




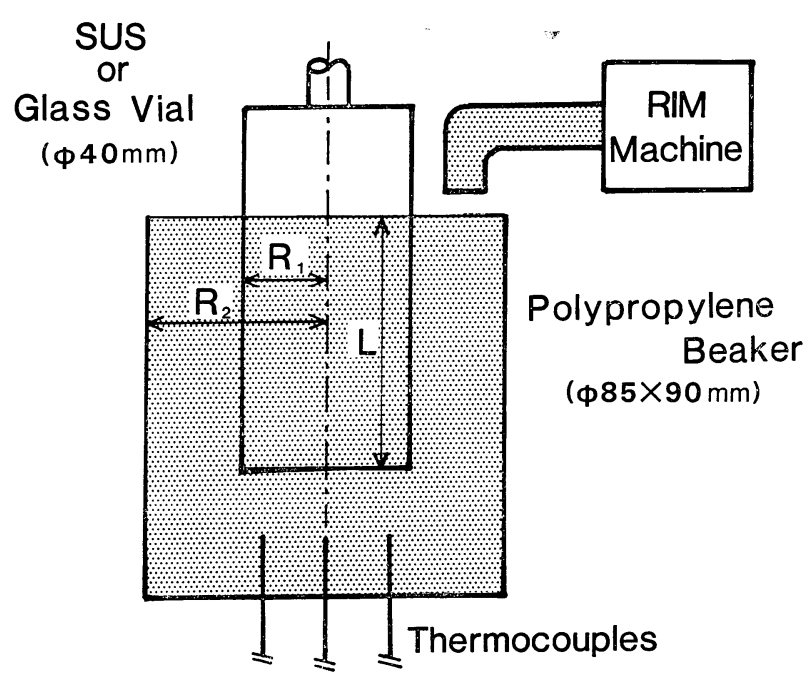

Fig. 3 Outline of the wide-gap Couette geometry of viscometer.

と内筒角速度 $\omega(=2 \pi \Omega)$ より次式で与兄られる。

$$
\eta=\frac{M}{4 \pi \omega L}\left(\frac{1}{R_{1}{ }^{2}}-\frac{1}{R_{2}^{2}}\right)
$$

ただし， $L$ は内筒浸液長， $R_{1}, R_{2}$ はそれぞれ内筒, 外筒の半 径である。

な特，標準粘度を持つシリコーンオイル $(1,10 \mathrm{~Pa} \cdot \mathrm{s}$, 信越化学 製）を用いて, 内筒回転数約 100 ～500 rpm の範囲で粘度を測定 し, 測定精度を検証した. 粘度 1 〜 $10 \mathrm{~Pa} \cdot \mathrm{s}$ の範囲で測定精度は約 10\%の䛊差を持つことがわかった. しかし， RIM 用 CAE シス テムのためのデータとしては充分な精度であると考兄られる。

$2 \cdot 3$ 測 定

一定速度で内筒を回転させた状態で， RIM 成形機より材料を レオメーター射出し，材料のゲル化直前までトルク測定を行った． また, 材料の温度測定は最大温度に到達するまで実施した。 成形 条件执よび測定条件を Table II に示す。なお，マイクロコンピ ュータによるデータの測定間隔は 30ms とした.

重合過程に挌けるポリウレタンの粘度は, 粘度約 $4 \mathrm{~Pa} \cdot \mathrm{s}$ では 剪断速度 $(\dot{\gamma})$ 約 $10^{3}$ まで依存性を持たないことが報告されて いる ${ }^{19)}$. 本研究にて用いた RIM 材料の粘度は, 回転数 100〜300 $\mathrm{rpm}\left(\dot{\gamma}=27 \sim 81 \mathrm{~s}^{-1}\right)$ の範囲では $\dot{\gamma}$ 依存性を持たないことを確認 した.

Table II. Molding conditions for viscosity measurement and rotational speed of the rheometer for various $\mathrm{RIM}$ systems: $\mathrm{A}$ and $\mathrm{B}$ indicate the components of the polyurethane RIM system (see Fig. 1).

\begin{tabular}{lcccc}
\hline \multicolumn{1}{c}{ Urethane system } & & $S_{1}$ & $S_{2}$ & $S_{3}$ \\
\hline Injection pressure $\left(10^{7} \mathrm{~Pa}\right)$ & $\mathrm{A}$ & 1.80 & 1.78 & 1.71 \\
& $\mathrm{~B}$ & 1.83 & 1.15 & 1.79 \\
Injection temperature $\left({ }^{\circ} \mathrm{C}\right)$ & & 29 & 33 & 28 \\
Mixing time $(\mathrm{s})$ & 0.88 & 1.00 & 0.70 \\
Rotational speed $(\mathrm{rpm})$ & 300 & 300 & 300 \\
\hline
\end{tabular}

\section{3. 結果および考察}

\section{$3 \cdot 1$ ポリウレタンの断熱反応における温度・粘度測定}

材料 $S_{1}$ の断熱反応に和ける温度 - 粘度の測定結果を Fig. 4 に 示す. 反応中の材料の温度分布は約 $55^{\circ} \mathrm{C}$ 以内で反応は注ぼ一様 に進行し, Fig. 4 に示した温度は 3 本の熱電対による測定值の 平均值とした。

トルクは射出終了後約 3 秒で材料のゲル化に伴い急激に上昇し た. ダル化時間が約 3 秒と短いことと，材料の熱伝導率が低いこ とより，測定中に系の断熱条件は充分成立していると考㝋られる。

次に，式(1)より計算した粘度を Fig. 5 に示す．材料の粘度は， 反応初期には微減しその後ら゙ル化に伴い急激に上㫒した．一方， 材料の温度は, 射出直後から急激に上昇し約 10 秒後に最高温度に 到達した。 これらの結果は, Macosko ら ${ }^{23)}$ の結果と一致する. 重合過程に拈ける粘度変化は温度と反応率 (分子量) 依存性を持 ち, 反応初期の粘度の微減は, 重合に伴弓粘度上年上りも温度上 昇による粘度減少の方が勝ったためであると考兄られる。材料 $S_{2}, S_{3}$ についても定性的には同じ結果が得られた。

各材料の最大温度 $T_{\mathrm{ad}}$, 断熱温度上㫒 $\Delta T_{\mathrm{ad}}\left(T_{\mathrm{ad}}\right.$ と射出温度 との差）を Table III にまとめる。材料 $S_{1}$ と $S_{2}$ は類似した性質 を示した。一方，材料 $S_{3}$ は温度上早が相対的に緩く， $S_{1}, S_{2}$ と 比較して約 $40^{\circ} \mathrm{C}$ 低い $\Delta T_{\mathrm{ad}}$ を示した. 材料による差異は, 主とし て架橋剤の違いによるものと考穴られる。

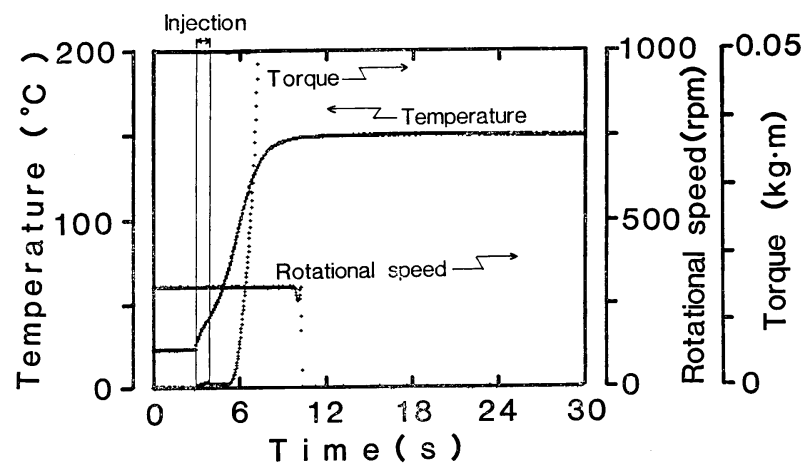

Fig. 4 Changes of temperature, torque and rotational speed during adiabatic reaction of urethane system $S_{1}$.

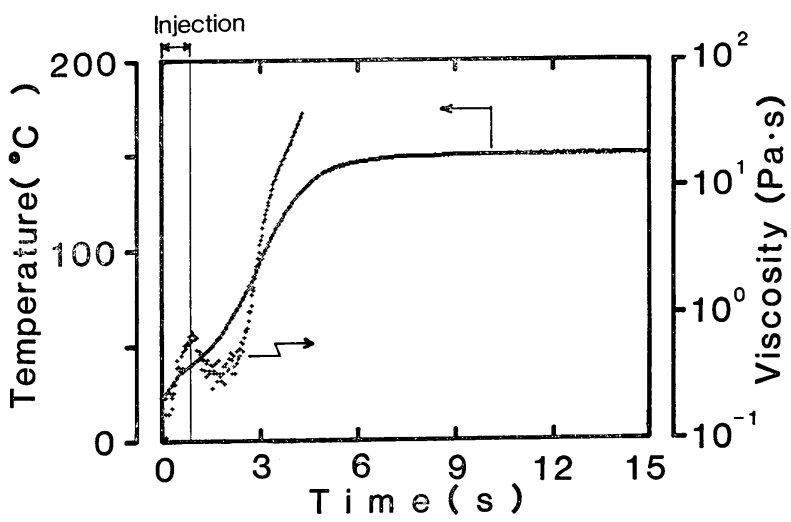

Fig. 5 Adiabatic temperature and viscosity changes of urethane system $S_{1}$. 
Table III. Adiabatic temperature rises for three urethane systems.

\begin{tabular}{lrrrr}
\hline \multicolumn{1}{c}{ Urethane system } & & $S_{1}$ & \multicolumn{1}{c}{$S_{2}$} & \multicolumn{1}{c}{$S_{3}$} \\
\hline Maximum temperature & $T_{\mathrm{ad}}\left({ }^{\circ} \mathrm{C}\right)$ & 149 & 152 & 108 \\
Injection temperature & $\left({ }^{\circ} \mathrm{C}\right)$ & 29 & 33 & 28 \\
Adiabatic temperature rise & $\Delta T_{\mathrm{ad}}\left({ }^{\circ} \mathrm{C}\right)$ & 120 & 119 & 80 \\
\hline
\end{tabular}

このよ5に, 開発したレオメータにより各 RIM 材料の反応性 の特徴をとらえることができた，

\section{$3 \cdot 2$ 材料定数の決定}

Macosko $5^{24)}$ は, RIM 材料の粘度 $\eta$ の温度 $T$ と反応率 $\chi$ 依存 性として, 次式を半経験的に導出した.

$$
\eta=\eta_{\infty} \exp \left(\frac{T_{1}}{T}\right) \cdot\left(\frac{\chi_{\mathrm{g}}}{\chi_{\mathrm{g}}-\chi}\right)^{\mathrm{a}+\mathrm{b} x}
$$

ここで， $\chi_{\mathrm{g}}$ はゲル化時の反応率で, $\eta_{\infty}, T_{1}, a, b$ は材料パラメ ータである.

また, RIM 材料の化学反応機構をアレニウス型の温度依存性 を持つ $n$ 次の反応速度式で近似すると, 反応速度 $R_{\mathrm{A}}$ は

$$
R_{\mathrm{A}}=\frac{\partial \chi}{\partial t}=K(1-\chi)^{\mathrm{n}} \exp \left(-\frac{T_{2}}{T}\right)
$$

で与えられる。 ここで, $t$ は時間， $K, n, T_{2}$ は材料パラメータ である。

本研究の目的の一つは, 短いゲル化時間を持つ RIM 材料の式 (2)，(3)に拈ける材料パラメータを決定することである。これらの パラメータは, 断熱反応に打ける温度と粘度曲線とを用いて, カ ーブフィッティングの手法で計算することができる(11),12). Fig. 5 のデータを用いて，最小二乗法により得た材料 $S_{1}$ のパラメータ をTable IV に示す。

な怙, 高粘度領域では測定液と内筒表面との䟝離が生じ, 粘度 の測定精度が著しく低下した。 このため, 粘度式に拈けるパラメ 一タの決定には $\chi<0.5$ の低粘度領域のデータを用いた。 また, ゲル化時の反応率 $\chi_{\mathrm{g}}$ は材料パラメータであり, 本来は材料ごと に決定されるべき值であるが, 高粘度領域での測定精度が低く $\chi_{\mathrm{g}}$ を決定することが不可能であった，そこで， $\chi_{\mathrm{g}}$ として Macosko ら ${ }^{16)}$ とよって 3 量体のポリオールと 2 量体のイソシアネート系で

Table IV. Rheological and kinetic parameters, which were determined by using the data in Fig. 5, for urethane system $S_{1}$.

Parameters in eq. (2)

\begin{tabular}{clc}
\hline$\eta_{\infty}$ & $(\mathrm{Pa} \cdot \mathrm{s})$ & $2.13 \times 10^{-9}$ \\
$T_{1} \quad(\mathrm{~K})$ & $6.04 \times 10^{3}$ \\
$a$ & & $-1.88 \times 10^{-4}$ \\
$b$ & 6.68 \\
\hline Parameters in eq. (3) & \\
\hline$K \quad\left(\mathrm{~s}^{-1}\right)$ & $6.19 \times 10^{3}$ \\
$n$ & & 1.19 \\
$T_{2}$ & $(\mathrm{~K})$ & $3.31 \times 10^{3}$ \\
\hline
\end{tabular}

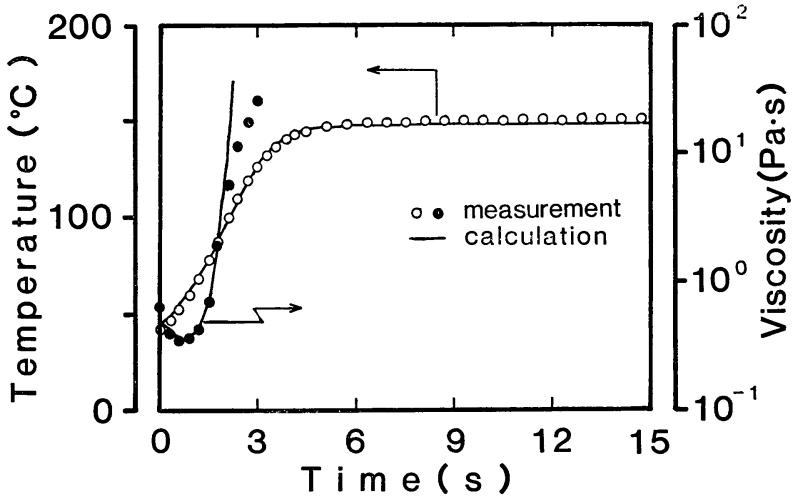

Fig. 6 Comparison between the experimental and the calculeted values for temperature and viscosity changes.

の重合反応の場合に理論的に計算された值 $\left(\chi_{\mathrm{g}}=0.707\right)$ を用い た. 本研究では低粘度領域のデータを用いてカーブフィッティン グを実行し，これは高粘度側の測定データに低い重みを乗じて最 小二乗近似を行ったことに効応するが， RIM 成形過程の流動シ ミュレーションでは低粘度領域でのデータが重要であるため, 妥 当な方法であると考えられる。

また，本研究に用いた材料は反応性が高く，ゲル化時間が約 3 秒と短い。これに対して, 射出時間約 1 秒で断熱反応に拮ける材 料の温度 ·粘度測定を実施した. このため, 材料の射出中もすで にレオメータに射出された材料は反応が進行し, 測定データは重 合開始洔間の異なる材料を混合した平均值である. しかし, 現実 の RIM そ扔いても重合開始時間の異なる材料が流動し, 金型内 流動中に対流等により材料の混合が生じるため, 流動過程のシミ ュレーションのためのデータ測定としては充分であると考えられ る.

断熱下に抬ける系の温度は次式に従 5 .

$$
\rho C_{\mathrm{p}} \frac{\partial T}{\partial t}=H R_{\mathrm{A}}
$$

なお，材料の密度を $\rho$, 比熱を $C_{\mathrm{p}}$, 反応熱を $H$ とした。式(4) を積分することによって $H / \rho C_{\mathrm{p}}=\Delta T_{\mathrm{ad}}$ なる関係が得られ, 式 (4)は次式のよ5に変形することができる.

$$
\frac{\partial T}{\partial t}=\Delta T_{\mathrm{ad}} R_{\mathrm{A}}
$$

Table IV の材料パラメータを用いて, 式(2), (3), (5)より差分 法により温度 ·粘度を計算した結果を Fig. 6 に示す. 計算値と 実測值とは良く一致した。

\section{$3 \cdot 3$ RIM 材料の 1 次元熱伝導解祈}

RIM に扣ける熱伝導解析は, 反応に伴い材料が発熱する点で 熱可塑性樹脂の射出成形飞执ける熱伝導解析と相違する. RIM 成形品は 3 次元形状を持つが, 一般に薄肉であり, 材料の熱伝導 率入が低いため成形品の熱伝導計算は 1 次元で充分であると考兄 られる。

$z$ 軸方向を肉厚方向とすると, 材料の温度 $T$ は次の支配方程式 飞従う。

$$
\rho C_{\mathrm{p}} \frac{\partial T}{\partial t}=\lambda \frac{\partial^{2} T}{\partial z^{2}}+H R_{\mathrm{A}}
$$


ここで，右辺第 2 項が発熱項である.

式(3)，(6)を差分法で解く FORTRAN プログラムを開発し， Table IV の材料パラメータを用いて，肉厚 $10 \mathrm{~mm}$ を持つ平板の 肉厚方向の熱伝導計算を実施した。 な拈，計算には次に示す条件 特よび近似を用いた。

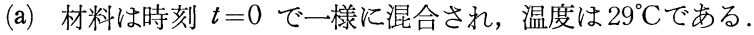

(b) 金型温度は一定温度 $29^{\circ} \mathrm{C}$ を保つ.

(c) 金型と材料との界面は，熱伝達率 $2.5 \times 10^{2} \mathrm{~J} / \mathrm{m}^{2} \cdot \mathrm{s}$ の熱伝 達境界である。

（d）比熱，密度，熱伝導率，反応熱は反応により変化しない，

(e) $\alpha=\lambda / \rho C_{\mathrm{p}}=8.9 \times 10^{-8} \mathrm{~m}^{2} / \mathrm{s}^{4)}$

(f) $H / \rho C_{\mathrm{p}}=\Delta T_{\mathrm{ad}}=120^{\circ} \mathrm{C}$

な持，条件(a)，(b)に拈ける温度は，断熱反応に括ける温度・粘 度測定時の材料の射出温度である。また，(d)に抢ける物性值は厳

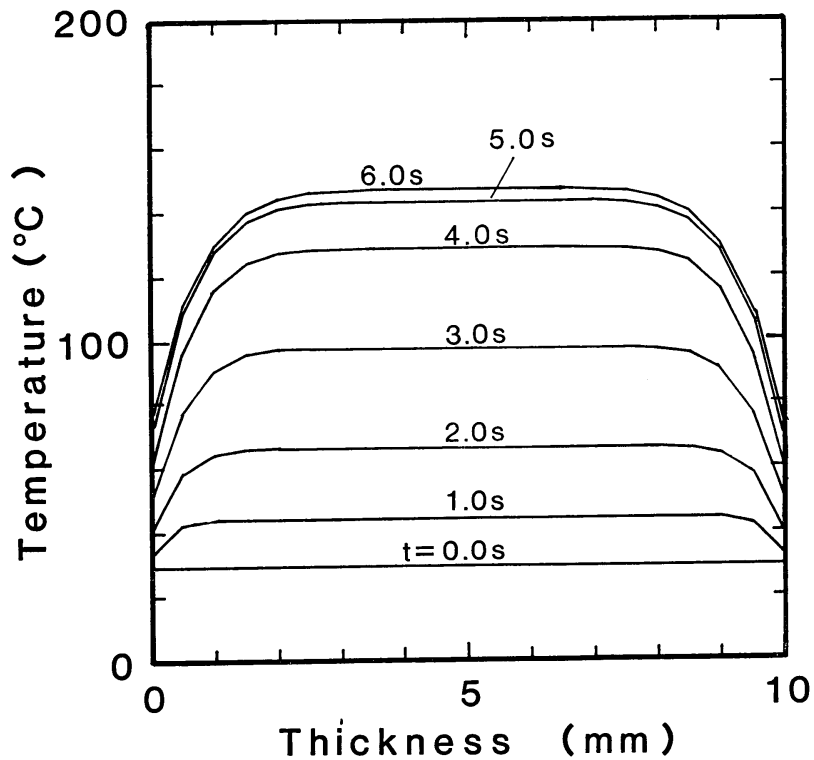

(a) $0 \leqq t \leqq 6 \mathrm{~s}$

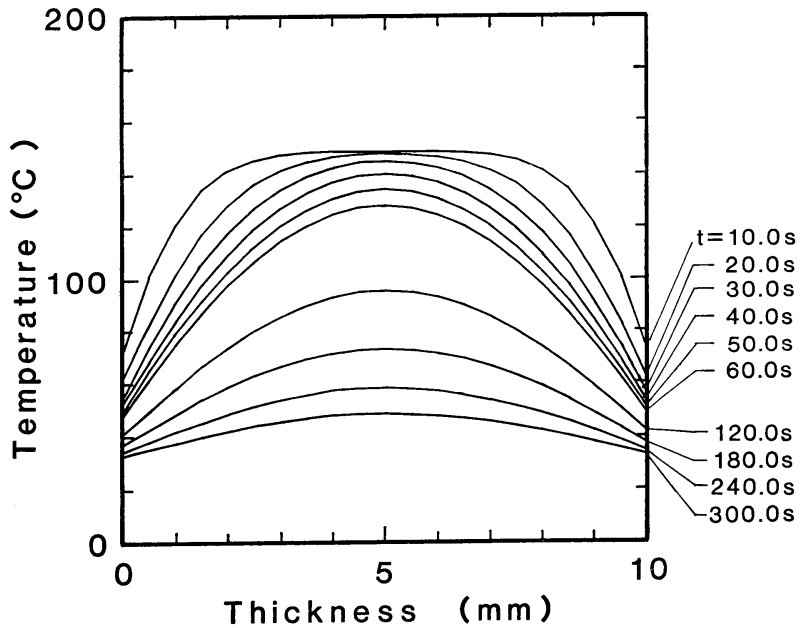

(b) $10 \leqq t \leqq 300 \mathrm{~s}$

Fig. 7 Calculated temperature distributions of $10 \mathrm{~mm}$ thick polyurethane plate at the various elapsed times.
密には反応率依存性を持つ。しかし，RIM に淤ける樹脂流動過 程は短時間であり重合度（粘度）も低いことより，(d)の近似は樹 脂流動過程では充分な近似であると考学られる。

肉厚方向の材料温度と区応率の時間変化をそれぞれ Fig. 7, 8 に示す. 反応初期には反応率の増加に伴 発熱に上り材料温度が 上年し，反応終了後金型への熱流出のため材料温度が低下寸る様 子を計算することができた。

Fig. 7 に扔いて反応初期（約 10 秒まで）には，材料の中央部 付近では温度勾配がなく，核ぼ断熱状態が保持されていることを 示している.これは反応速度と比較して材料の熱伝導率が低いこ とに起因する。また，断熱条件下では系の温度は式(5)に従い， Fig. 7 の計算に用いた比熱, 密度は文献值であるが, 断熱条件 が成立する領域ではこれらのデータは参照されない，そこで, 計

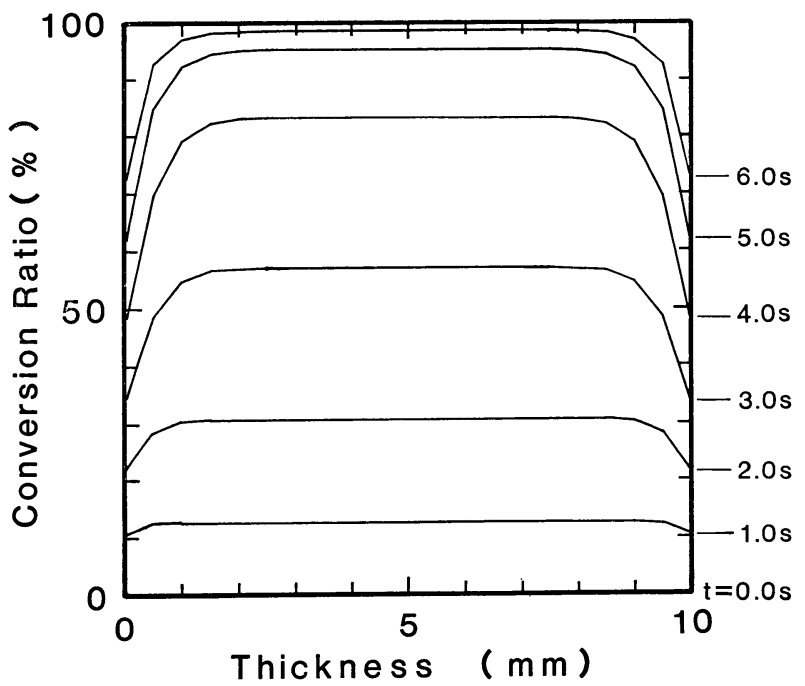

Fig. 8 Distributions of calculated conversion ratio for $10 \mathrm{~mm}$ thick polyurethane plate at the various elapsed times. $(0 \leqq t \leqq 6 \mathrm{~s})$

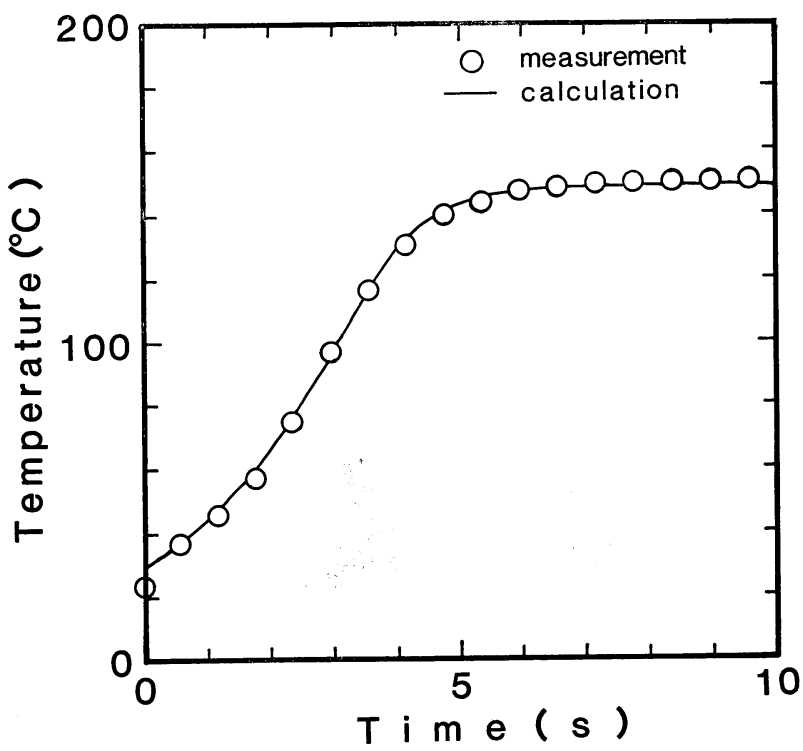

Fig. 9 Comparison between the experimental (Fig. 5) and calculated (Fig. 7) temperature profiles. 
算した Fig. 7 の材料中央部の温度変化と Fig. 5 に示した断熱条 件下での温度測定值との比較により, 開発した熱伝導解析プログ ラムを検証することができる．計算值と実測值との比較をFig. 9 に示す，両者は良く一致した．な括，計算には射出時間が含まれ ていないため, 計算と実測に乱ける時間の原点を一致させること ができない，そこで，以下に述べる操作を行った．

断熱反応に招ける温度 ·粘度測定に和いて, 材料の射出中は外 筒内で反応中の材料に更に未反応液が射出され混合される．この とき反応率を単純平均し, 反応が混合後も式(3)に従5と仮定する と, 射出中の材料の反応率は次式に従うことが示される.

$$
\begin{aligned}
& \frac{\partial \chi}{\partial t}=-\frac{\chi}{t}+K(1-\chi)^{\mathrm{n}} \exp \left(-\frac{T_{2}}{T}\right) \\
& T(t)=\Delta T_{\mathrm{ad}} \cdot \chi+T(0)
\end{aligned}
$$

Table IV の材料パラメータを用いて， $T(0)=29^{\circ} \mathrm{C}$ として式(7), (8)より射出終了時間 $t=0.88 \mathrm{~s}$ での材料温度を計算すると $T=35.3$ ${ }^{\circ} \mathrm{C}$ とる。 そこで, 温度が $35.3^{\circ} \mathrm{C}$ に計算值と実測值とが一致する ように Fig. 9 を作図した.

\section{4. 結語}

本研究では, ウレタンの反応機構の解明および粘度の温度 · 反 応率依存性の測定を目的として RIM 用レオメータを開発し, 非 発泡系ウレタン材料の断熱反応に乱ける温度・粘度測定を実施し た. 最小二乗法により決定した粘度式拉よび反応速度式に和ける 材料パラメータを用いて行った断熱反応のシミュレーションの結 果は, 実測值とよく一致した。 この結果, 本レオメータにより RIM 材料の成形性を定量的に評価でき，ポリウレタンの RIM 過程を解析する CAE システムで必要な材料特性值を測定するこ とができた。

また， RIM 材料の 1 次元熱伝導解析プログラムを開発し，決 定した材料パラメータを用いてウレタン材料の 1 次元熱伝導計算 を実施したところ，計算値と実測值とは良く一致した。

（年会にて一部発表済み

発表年月日 : 平成元年 5 月 18 日

講 演会名:日本レオロジー学会 第16年会)

\section{文献}

1) Becker, W.E., "Reaction Injection Molding”, W.E. Becker ed., (1979), Van Nostrand Reinhold, New York, Ch. 1.

2) Castro, J.M., and C.W. Macosko, AIChE J., 28, 250 (1982).

3) Castro, J.M., S.D. Lipshitz, and C.W. Macosko, AIChE
J., 28, 973 (1982).

4) Estevez, S.R., and J.M. Castro, Polym. Eng. Sci., 24, 428 (1984).

5) Lekakou, C.N., and S.M. Richardson, Polym. Eng. Sci., 26, 1264 (1986).

6) Manas-Zloczower, I., J.W. Blake, and C.W. Macosko, Polym. Eng. Sci., 27, 1229 (1987).

7) Lack, C.D., and C.A. Silebi, Polym. Eng. Sci., 28, 434 (1988).

8) Vespoli, N.P., L.M. Alberino, A.A. Peterson, and J.H. Ewen, J. Elast. Plast., 18, 159 (1986).

9) Manzione, L.T., and J.S. Osinski, Polym. Eng. Sci., 23, 576 (1983).

10) Kim, D.H., and S.C. Kim, Polym. Compos., 8, 208 (1987).

11) Lipshitz, S.D., and C.W. Macosko, J. Appl. Polym. Sci., 21, 2029 (1977).

12) Richter, E.B., and C.W. Macosko, Polym. Eng. Sci., 18, 1012 (1978).

13) Steinle, E.C., F.E. Critchfield, J.M. Castro, and C.W. Macosko, J. Appl. Polym. Sci., 25, 2317 (1980).

14) Pannone, M.C., and C.W. Macosko, Polym. Eng. Sci., 28, 660 (1988).

15) Hsu, T.J., and L.J. Lee, Polym. Eng. Sci., 28, 955 (1988).

16) Broyer, E., and C.W. Macosko, AIChE J., 22, 268 (1976).

17) Lee, L.J., and C.W. Macosko, Int. J. Heat Mass Trans., 23, 1479 (1980).

18) Vespoli, N.P., and L.M. Alberino, Polym. Proc. Eng., 3, 127 (1985).

19) Lipshitz, S.D., and C.W. Macosko, Polym. Eng. Sci., 16, 803 (1976).

20) Perry, S.J., J.M. Castro, and C.W. Macosko, J. Rheology, 29, 19 (1985).

21) Biesenberger, J.A., R. Kumar, R. Garritano, and J.M. Starita, Polym. Eng. Sci., 25, 301 (1985).

22) Biesenberger, J.A., and R. Kumar, Polym. Proc. Eng., 4, 141 (1986).

23) Blake, J.W., W.P. Yang, R.D. Anderson, and C.W. Macosko, Polym. Eng. Sci., 27, 1236 (1987).

24) Castro, J.M., and C.W. Macosko, SPE ANTEC Tech. Papers, 26, 434 (1980). 